Biografistyka Pedagogiczna

Rok 6 (2021) nr 1

ISSN 2543-6112; e-ISSN 2543-7399

DOI: 10.36578/BP.2021.06.28

\title{
Renata Wawrzyniak-Beszterda*
}

\section{Wsparcie na starcie?}

\section{Z doświadczeń biograficznych początkujących nauczycieli}

\section{Support at the Start?}

From the Biographical Experiences of Novice Teachers

\begin{abstract}
The issue of paper concerns the biographical experience of novice teachers related to their professional start. An analysis of their narratives (reanalysis of free-targeted interviews), enabled to draw a map of social support present at school.
\end{abstract}

Keywords: novice teachers, professional start, professional development of a teacher, social support, qualitative data, re-analysis.

* Renata Wawrzyniak-Beszterda (ORCID: 00oo-0o01-5640-1784) - dr hab., pracuje w Pracowni Pedagogiki Szkolnej na Wydziale Studiów Edukacyjnych () na Uniwersytecie im. Adama Mickiewicza w Poznaniu, kontakt: rwb@amu.edu.pl. 


\section{Wpro wadzenie $^{1}$}

Drzebieg tranzycji ze świata edukacji akademickiej do świata pracy jest coraz L częściej przedmiotem badań realizowanych w obszarze nauk społecznych. Przejście związane ze zmianą domeny życiowej aktywności (uczelnia-szkoła) oraz statusową transformacją (student-pracownik) jest kluczowym epizodem w budowaniu kapitału kariery jednostki. Wydaje się, że z uwagi na specyfikę zawodu właśnie tranzycyjne doświadczenia nauczycieli są szczególnie istotne w procesie kształtowania ich profesjonalnych biografii. W tekście przybliżę zatem procesualny charakter rozwoju zawodowego nauczyciela, scharakteryzuję fenomen startu zawodowego, aby w odwołaniu do empirycznych ilustracji zarysować mapę wsparcia, z jakiego korzystają nowicjusze, aby lepiej radzić sobie z wymaganiami szkoły jako miejsca pracy. Analizie podam narracje nauczycieli uzyskane w swobodnych wywiadach ukierunkowanych.

\section{Potencjał wsparcia w starcie zawodowym nauczycieli}

Analizy biografii zawodowych nauczycieli pozwalają wyłonić swoiste schematy, układy, które pojawiają się w procesie przekształcania doświadczeń nauczyciela. Ale powtarzalność pewnych fenomenów w biegu życia zawodowego nauczyciela nie oznacza, że następują one w stałym układzie linearnym, w określonym następstwie temporalnym. Sekwencje, które pojawiają się w cyklu rozwoju zawodowego nauczyciela, mogą mieć różną długość, a przejścia między nimi mogą się zapętlać. Transformacja zawodowych doświadczeń nauczyciela jest nieciągła, dynamiczna, pełna zastojów i możliwych regresji, skokowych zrywów, przeplatających się ogniw. Nie chcę w tym miejscu rekonstruować licznych w literaturze pedeutologicznej prób rozpoznawania wzorów przejść/ścieżek/trajektorii profesjonalnych biografii nauczycieli, chodzi mi bowiem o zwrócenie uwagi, że właśnie taka specyfika rozwoju zawodowego wymusza ciągłe balansowanie, utrzymywanie przez nauczyciela dynamicznej równowagi między doświadczanymi przez niego obciążeniami w pracy zawodowej a wsparciem, które może czerpać

1 Fraza zastosowana przeze mnie w tytule („wsparcie na starcie”) jest dość często wykorzystywana w inicjatywach społecznych i biznesowych, co odzwierciedla siłę społecznie upowszechnionego przekonania o roli startu w przebiegu różnych działań. 
z szeroko pojętego otoczenia szkolnego. Radzenie sobie z wyzwaniami takiego środowiska pracy wymaga od nowicjusza dynamicznego potencjału biograficznego, który przejawia się m.in. w umiejętności przyjmowania informacji zwrotnych z otoczenia i uwzględniania ich w przyszłych działaniach².

Start zawodowy to okres, w którym początkujący nauczyciel konfrontuje się z nowymi dla niego zadaniami i oczekiwaniami w środowisku pracy stanowiącym przestrzeń zawodowej socjalizacji. Ewald Terhart podkreśla, że wchodzenie do zawodu nauczyciela jest kompleksowym, kryzysowym i indywidualnym procesem rozwojowym, który wynika ze współdziałania czynników osobowych i sytuacyjnych ${ }^{3}$. Jak wykazała w swych badaniach Manuela Keller-Schneider, jednostka jest postrzegana w tym układzie jako architekt własnej biografii, a nie ofiara okoliczności ${ }^{4}$. Stawanie się nauczycielem trafnie charakteryzuje Magdalena Grochowalska:

to proces długotrwały i złożony, na który wpływ mają różnorodne, czasami odmienne perspektywy, przekonania i praktyki. Dotyczą one formowania się tożsamości zawodowej, relacji interpersonalnych nawiązywanych w nowym kontekście społecznym, konstruowania wiedzy i rozwijania umiejętności niezbędnych do wykonywania zawodu. [...] Uzyskanie harmonii pomiędzy nauczaniem innych a uczeniem się zawodu to dylemat szczególnie wyraźnie widoczny w okresie rozpoczynania kariery zawodowej ${ }^{5}$.

Znaczenie tranzycyjnych doświadczeń nauczyciela w formowaniu jego profesjonalnej tożsamości jest trudne do przecenienia. Szczególną rolę odgrywa w tym kontekście wsparcie, które początkujący nauczyciel może uzyskać. Poczucie nieadekwatności i niewystarczalności własnych kompetencji wobec

2 D. Klus-Stańska, Ciągłość i zmiana czy bierność i niekontrolowane odruchy - w którym kierunku zmierza szkoła?, w: Ciągłość i zmiana w edukacji szkolnej-społeczne i wychowawcze obszary napięć, red. J. Surzykiewicz, M. Kulesza, Łódź 2010, s. 35-49.

3 E. Terhart, Lehrerberuf und Lehrerbildung. Forschungsbefunde, Problemanalysen, Reformkonzepte, Weinheim-Beltz 2001.

4 M. Keller-Schneider, Entwicklungsaufgaben im Berufseinstieg von Lehrpersonen. Beanspruchung durch berufliche Herausforderungen im Zusammenhang mit Kontext- und Persönlichkeitsmerkmalen, Münster 2010.

5 M. Grochowalska, Dylematy nowicjusza. Konteksty stawania się nauczycielem edukacji przedszkolnej, „Edukacja Elementarna”, 9 (2014) nr 1 (31), s. 27-40. 
złożonych wymagań zawodowych jest kluczowym rysem doświadczeń nowicjusza w szkole ${ }^{6}$. Sposoby radzenia sobie (konstruktywne lub nie) z tak rozpoznawanymi deficytami we własnych zasobach nie tylko konstruują profesjonalną biografię nauczyciela, ale odzwierciedlają też rozwojowy potencjał środowiska pracy. Ciekawe poznawczo i uzasadnione badawczo będzie zatem pytanie: jakich rodzajów wsparcia doświadczają początkujący nauczyciele na początku swej zawodowej kariery w szkole? Wydaje się, że ogląd szkoły przez pryzmat obecnego w niej wsparcia właśnie w wykonaniu nauczycieli-nowicjuszy, z uwagi na ich specyficzne usytuowanie w szkolnej przestrzeni, może być szczególnie wyrazisty, wyostrzony i nasycony.

W rozumieniu wsparcia społecznego odnoszę się do ujęcia reprezentowanego przez Helenę Sęk oraz Romana Cieślaka, którzy definiują wsparcie społeczne jako pomoc dostępną jednostce w sytuacji trudnej, zbliżającą ją do rozwiązania problemu czy przezwyciężenia trudności. Jego skuteczność uzależniają od stopnia zgodności między wsparciem oczekiwanym a uzyskanym. Wymiana społeczna o charakterze wsparcia sprzyja zmniejszeniu stresu, opanowaniu kryzysu poprzez towarzyszenie w nim, kształtowane w jej toku poczucie przynależności i bezpieczeństwa budzi nadzieję na przezwyciężenie trudności Przywoływani badacze wyróżniają przy tym dwa typy wsparcia: strukturalne i funkcjonalne ${ }^{7}$. Pierwsze ulokowane jest w obiektywnie istniejących sieciach społecznych pełniących wobec jednostki funkcje pomocowe. Drugie (funkcjonalne) osadzone jest w interakcjach społecznych podejmowanych przez uczestników w sytuacjach problemowych, stresowych lub krytycznych, w których dochodzi do przekazania/wymiany (jednostronnej lub dwustronnej) okre-

6 W. Dróżka, Młode pokolenie nauczycieli. Studium autobiografii młodych nauczycieli polskich lat dziewięćdziesiątych, Kielce 1997; H. Kwiatkowska, Pedeutologia, Warszawa 2008; D. Walczak, Początkujący nauczyciele. Raport z badania jakościowego, Warszawa 2012; J. Szempruch, Pedeutologia. Studium teoretyczno-pragmatyczne, Kraków 2013; M. Grochowalska, Dylematy nowicjusza, s. 27-40; H. Kędzierska, Nowicjusze: proces zakotwiczania w zawodzie nauczyciela, „Forum Oświatowe”, 27 (2015) nr 2 (15), s. 59-73.

7 H. Sęk, R. Cieślak, Wsparcie społeczne - sposoby definiowania, rodzaje i źródła wsparcia, wybrane koncepcje teoretyczne, w: Wsparcie społeczne, stres i zdrowie, red. H. Sęk, R. Cieślak, Warszawa 2004, s. 11-28; tegoż, Wsparcie społeczne jako kategoria zasobów, w: Zasoby osobiste i społeczne sprzyjające zdrowiu jednostki, red. Z. Juszczyński, N. Ogińska-Bulik, Łódź 2003, s. 17-32. 
ślonych zasobów. Wymieniane zasoby stanowią o rodzaju wsparcia ${ }^{8}$, tj. emocjonalnym, informacyjnym, instrumentalnym i materialnym. I tak wsparcie emocjonalne przejawia się w wyrażaniu emocji, które pełni funkcję uspokajającą, podtrzymującą, świadczy o pozytywnym stosunku do partnera interakcyjnego, stanowi wyraz troski o niego. Wsparcie poznawcze zaś sprowadza się do przekazu/wymiany informacji, które pozwalają „biorcy” zrozumieć sytuację trudną, problem, z którym się zmaga, rozpoznać warunki skuteczności podejmowanych działań. Przekaz, który dotyczy wskazań na temat sposobu postępowania oraz możliwych do zastosowania narzędzi a zatem rozwija umiejętności zaradcze jednostki, jest wsparciem instrumentalnym (stanowi swoisty instruktaż). Pomoc o charakterze rzeczowym czy finansowym określa się wsparciem rzeczowym, sprowadza się bowiem do przekazu dóbr materialnych. Przebieg i skuteczność wsparcia społecznego jest wielorako uwarunkowana: znaczenie mają zmienne kontekstowe, procesualne, osobowościowe i społeczne9 .

\section{Charakterystyka podejścia badawczego}

W próbie odpowiedzi na pytanie o wsparcie społeczne doświadczane przez nauczycieli w okresie ich startu zawodowego wykorzystam materiał empiryczny uzyskany $\mathrm{w}$ projekcie badawczym ${ }^{10}$, w którym zrealizowałam zbiorowe studium przypadku ${ }^{11}$, tj. instrumentalne studium obejmujące kilka przypadków ${ }^{12}$. Zastosowanym narzędziem gromadzenia danych empirycznych był

8 Kryterium wyodrębnienia stanowi treść wsparcia.

9 H. Sęk, R. Cieślak, Wsparcie społeczne - sposoby definiowania.

10 R. Wawrzyniak-Beszterda, Kapitał społeczny szkoły. Z doświadczeń biograficznych nauczycieli. Studium przypadków, Poznań 2019. Przedmiotem badań przedstawionych w przywołanej monografii uczyniłam kapitał społeczny szkoły rekonstruowany z biograficznych doświadczeń zawodowych nauczycieli w pierwszych latach ich pracy w szkole. Wykorzystałam koncepcję kapitału społecznego James S. Colemana, który sytuuje ten kapitał w przestrzeni mezo, przypisuje go strukturze społecznej, zwraca uwagę na jego emergentny charakter i produktywną rolę.

11 R. E. Stake, Jakościowe studium przypadku, w: Metody badań jakościowych, t. 1, red. N. K. Denzin, Y. S. Denzin, tłum. M. Sałkowska, Warszawa 2009, s. 623-654.

12 Instrumentalność zbiorowego studium wyrażała się w tym, że analizowane przypadki stanowiły narzędzie do uzyskania wglądu w zjawisko kapitału społecznego szkoły; tamże. 
wywiad swobodny ukierunkowany, który pozwolił na uchwycenie subiektywnego znaczenia zdarzeń/procesów/zjawisk/zachowań/opisów konstruujących profesjonalne biografie nauczycieli. Scenariusz wywiadu obejmował ogólne dyspozycje, a formułowane pytania skupione były wokół kilku osiowych kwestii: przesłanek podjęcia decyzji o zawodzie nauczyciela, przebiegu akademickiego przygotowania do pracy w szkole, okoliczności przyjęcia do pracy, doświadczeń związanych ze startem zawodowym, ewolucji zawodowego funkcjonowania oraz autorefleksji dotyczącej bycia nauczycielem.

W prezentowanym wywodzie przedstawiam rezultaty powtórnej jakościowej analizy treści ${ }^{13}$ części zgromadzonego wówczas materiału empirycznego, tj. narracji nauczycieli w sekwencjach dotyczących ich startu zawodowego. W reanalizie wykorzystuję transkrypty przeprowadzonych wywiadów. Próbę badawczą stanowi siedmioro nauczycieli (rocznik 1986), dla których wspólnym biograficznym doświadczeniem było zatrudnienie w szkole i kilkuletni (4-6 lat) staż pracy $\mathrm{w}$ momencie prowadzenia wywiadu ${ }^{14}$. Wywiady realizowałam w warunkach zapewniających komfort rozmowy, umożliwiających też jej nagranie (za zgodą rozmówcy), pojedyncze wywiady trwały od 2,5 do 4 godzin.

Pracę z tak uzyskanym korpusem danych prowadziłam, wykorzystując warsztat zaproponowany przez Grahama Gibbsa ${ }^{15}$ : analiza treści transkryptów pozwoliła wyłonić pola tematyczne, wstępnie uporządkowany materiał empiryczny poddałam kodowaniu otwartemu. Zależało mi bowiem na odczytaniu subiektywnych sensów i znaczeń nadawanych przez nauczycieli ich doświadczeniom związanym z rozpoczęciem pracy w szkole. $\mathrm{Na}$ etapie kodowania skoncentrowanego użyłam kategorii uczulających wyprowadzonych z koncepcji wspar-

13 Kwestie związane z ponownym wykorzystaniem danych pochodzących z zakończonych badań jakościowych rozwijają w swoim tekście Marta Karkowska i Magdalena Bielińska. Autorki zarysowują pożytki płynące z „powrotu” do „starych danych" z badań oraz potencjał różnych sposobów realizowania powtórnych podejść (re-use, re-visits, re-analyses); M. Karkowska, M. Bielińska, Po co nam "stare wywiady"? $O$ ponownym wykorzystaniu danych $z$ badań jakościowych (rewizytach, reanalizach i nie tylko), „Przegląd Socjologii Jakościowej”, 15 (2019) nr 2, s. 12-39.

14 Szczegółowy opis konstruowania próby badawczej: R. Wawrzyniak-Beszterda, Kapitat spoteczny szkoły.

15 G. Gibbs, Analizowanie danych jakościowych, tłum. M. Brzozowska-Brywczyńska, Warszawa 2011. 
cia społecznego. Przejście w postępowaniu badawczym z początkowych kodów opisowych (osadzonych w doświadczeniach badanych odzwierciedlonych w ich narracjach) do kodów analitycznych (wyprowadzonych z założeń teoretycznych) znajduje swe uzasadnienie w procedurach jakościowej analizy treści: „Teoretyczna baza badań dostarcza kontekstu przy podejmowaniu decyzji, jak będzie przebiegała analiza wywiadu. Różne techniki analizy to sposoby uzyskiwania odpowiedzi na różne pytania. Koncepcje teoretyczne analityka odnośnie przedmiotu badania wpływają na to jak on/ona analizuje wywiady. Analiza wywiadu może być częścią tworzenia jak i zastosowaniem lub weryfikacją teorii" ${ }^{16}$. Podkreślić trzeba, że na tym etapie w każdej sieci kodów (dotyczącej określonego rodzaju wsparcia społecznego) wyodrębniały się w toku analiz swoiste skupienia tematyczne obejmujące charakterystyczne zjawiska/epizody/opisy/zachowania/oceny dotyczące różnych przejawów wsparcia doświadczanego przez początkujących nauczycieli. Kody budujące te skupienia w toku sukcesywnie prowadzonej analizy podlegały dynamicznym zmianom, przekształceniom i uzupełnieniom. Chodziło mi bowiem o to, aby nie utracić w procesie opracowywania danych unikatowości, zróżnicowania i swoistości doświadczeń biograficznych uczestników badań związanych z otrzymywanym wsparciem na początku ich pracy w szkole.

Skupiam się na czasowo limitowanym fragmencie biografii początkujących nauczycieli obejmującym ich start zawodowy. Pytania inicjujące wywiady dotyczyły zawodowych początków badanych, ale wątki z tym związane pojawiały się w wypowiedziach rozmówców wielokrotnie, były rozwijane, doprecyzowywane, poszerzane o opisy kolejnych epizodów/zdarzeń oraz ich oceny. Korpus obecnie analizowanych narracji dotyczących startu zawodowego mogłam wyodrębnić dzięki wcześniej przeprowadzonej wertykalnej charakterystyce biografii zawodowych uczestników badania ${ }^{17}$. W wypowiedziach nauczycieli pojawiały się bowiem zazwyczaj epizody, wydarzenia, autorefleksje, oceny własnych odczuć świadczące o nabyciu takich cech w funkcjonowaniu zawodowym badanych, które wskazywały na dokonaną transformację w ich profesjonalnej biografii. Przemiana rozpoczynała nowy rozdział w ich pracy jako nauczycieli, a więc subiektywnie zamykała ich start zawodowy. Choć oczywiście to „zakończenie”

16 S. Kvale, InterViews. Wprowadzenie do jakościowego wywiadu badawczego, tłum.

S. Zabielski, Białystok 2004, s. 209.

17 Ich omówienie R. Wawrzyniak-Beszterda, Kapitał społeczny szkoły. 
nowicjatu stanowi płynną granicę, dotyczy momentu realizacji wywiadu. Późniejsze doświadczenia, nowe wyzwania, przekształcanie sytuacji zawodowej, zachodzące tranzycje w pozazawodowych obszarach życia nauczycieli stanowią (potencjalnie) okoliczności mogące prowadzić do „zapętlenia” profesjonalnej biografii nauczyciela i ponownego uruchomienia doświadczeń i strategii radzenia sobie z nimi, wpisujących się specyfikę startu zawodowego.

Wybrany przeze mnie sposób pracy z materiałem empirycznym umożliwia, na bazie zbiorowego studium przypadku, zarysowanie portretu badanego zjawiska w ujęciu przekrojowym (horyzontalna analiza przypadków, a nie wertykalna). Tak ukierunkowana eksploracja badawcza stanowi głos w diagnozowaniu szkoły jako środowiska pracy, umożliwia bowiem swoiste zmapowanie szkoły z uwagi na rodzaje wsparcia obecne w jej społecznej przestrzeni. Doświadczenia biograficzne nauczycieli gromadzone przez nich na początku pracy w szkole traktuję jako rezultat scalania jednostkowej biografii z jej społecznym kontekstem ${ }^{18}$. W takim ujęciu kategoria doświadczenia oznacza uwzględnienie tożsamościowej (biograficznej) strony zjawisk społecznych ${ }^{19}$. Jak wspominałam wcześniej, wyróżniane w literaturze przedmiotu rodzaje wsparcia społecznego wykorzystałam w pracy z korpusem zgromadzonych danych. Pojawiające się w narracjach sekwencje doświadczeń/uzasadnień/ocen/zdarzeń/zachowań/wrażeń wzajemnie się nakładały, tworząc unikatowe konfiguracje przejawów wsparcia społecznego dostępnego w szkole każdemu z badanych nauczycieli. Czytelność wywodu wymaga jednak zastosowania pewnych uproszczeń i arbitralnych rozwiązań w kategoryzowaniu odsłanianych w analizie fenomenów. Dlatego prezentację rezultatów przeprowadzonych analiz poprowadzę, charakteryzując skupienia kodów tematycznych zbudowanych wokół kategorii uczulających (tj. rodzajów wsparcia: emocjonalnego, informacyjnego, instrumentalnego oraz rzeczowego). Omówienie wyników tak realizowanej analizy jakościowej niesie ze sobą niebezpieczeństwo zbytniej szczegó-

18 N. K. Denzin, Reinterpretacja metody biograficznej $w$ socjologii: znaczenie a metoda $w$ analizie biograficznej, tłum. N. Nowakowska, w: Metoda biograficzna w socjologii, red. J. Włodarek, M. Ziółkowski, Warszawa-Poznań 1990, s. 55-70.

19 M. Domecka, Praca jako doświadczenie biograficzne, w: Konstruowanie jaźni i społeczeństwa. Europejskie warianty interakcjonizmu symbolicznego, red. E. Hałas, T. Konecki, Warszawa 2005, s. 229-250. 
łowości i rozwlekłości z jednej strony ${ }^{20}$, z drugiej natomiast prowadzić może do skonstruowania wywodu, bez wystarczającego osadzenia w zgromadzonym materiale empirycznym ${ }^{21}$. Dlatego przywoływane cytaty z wypowiedzi badanych, odzwierciedlające analizowane kategorie tematyczne (pojedyncze lub całe ich grupy/skupienia), przywołuję bez nadmiernej ingerencji w ich treść. Czasem jedynie wypowiedź jest kondensowana, lecz każdorazowo taki zabieg zaznaczam znakiem (trzykropek w nawiasie). Jaki zatem obraz szkolnego wsparcia społecznego można zrekonstruować z biograficznych doświadczeń zawodowych nauczycieli-nowicjuszy?

\section{Wsparcie społeczne doświadczane przez początkujących nauczycieli - ilustracja empiryczna}

W siatce kodów zbudowanej wokół wsparcia emocjonalnego doświadczanego przez początkujących nauczycieli wyłonić można w zasadzie dwa skupienia tematyczne zróżnicowane ze względu na nadawców tego rodzaju przekazów. Epizody związane z obdarzaniem początkujących nauczycieli komunikatami podtrzymującymi, wyrażającymi troskę i pomoc, budującymi poczucie pewności i bezpieczeństwa, kształtującymi atmosferę zrozumienia, zachęty i uznania związane były po pierwsze, z nauczycielami ze szkoły, po drugie, z uczniami (i ich rodzinami).

Nauczycielskie okazywanie wsparcia ma swoją specyfikę, którą odzwierciedlają wyłonione kategorie tematyczne kodów. Otóż odczuwane przez nowicjuszy wsparcie emocjonalne ze strony innego (doświadczonego) nauczyciela jest osadzone w indywidualnej relacji interpersonalnej z nim, przy czym pojawienie się tej specyficznej, silnej więzi w subiektywnej ocenie badanych było czymś niewytłumaczalnym, odbieranym jako dar/zrządzenie losu, szczęśliwy/opatrznościowy przypadek.

20 Steinar Kvale trafnie podkreśla w tym kontekście: „wywiady mogą być nudne, do czytania, banalne, zawierają powtórzenia, małą wewnętrzną spójność albo są pozbawione większego znaczenia. To właśnie od badacza domagamy się, aby wykazał perspektywę i konteksty., które sprawią, że wywiady staną się czytelne, albo zajmujące dla czytelnika"; S. Kvale, InterViews, s. 266.

21 W tym przypadku Kvale zwraca uwagę na niebezpieczeństwo poszatkowania wywiadu na krótkie cytaty, które nie oddają kontekstu ani uzasadnień/wyjaśnień badanych. 
[...] to są fajne koleżanki, jak są jakieś imprezy to my rozmawiamy [...], ale nie są to na tyle bliskie relacje, co, co właśnie z Anną i gdzieś tam i no nie wiem, może przypadek, może tak miało być, ale, ale mówię ja jestem jej bardzo wdzięczna, że tak, że tak mnie wprowadziła i no tak, no fajne, fajne $(\text { Ewa ENP6) })^{22}$.

Pani dyrektor się śmiała, że mówi, to ja nie wiem, ja tak, no przyszłaś i mówi nie wiem czemu, po prostu tak jakoś poczułam, że Ciebie muszę przyjąć i, i to był jakoś taki przypadek. No nie wiem, jak to inaczej tak nazwać (Katarzyna KNG1).

Kiedyś np. też miałam jakiś tam problem. Akurat nie było nikogo i tam taka nauczycielka właśnie, taka polonistka i się zapytałam i ona dokładnie mi tam wszystko powiedziała, też ona taka, tak też, tak bardziej traktowała mnie widziałam jak córkę, bo tam miała dzieci w moim wieku i tam, ona zawsze tak jakoś nigdy nie było problemu, że, żeby coś o nią zapytać. Ona zresztą sama mówi, a co tam, jak sobie radzisz, a co tam Ci pomóc? (Katarzyna KNG1).

Początkujących nauczycieli wspierają emocjonalnie koledzy/koleżanki o specyficznych cechach osobowych. Narracje zawierające takie opisy/epizody budują drugą grupę kodów tematycznych w omawianym skupieniu.

Anna mi mówi, że no będzie dobrze, będzie dobrze [...] od tamtego czasu się mną opiekuje i w ogóle, no naprawdę bardzo fajna koleżanka [...] bo to jest, tak naprawdę bardzo dobry człowiek [...] (Ewa ENP6).

[...] zawsze mogłam podejść i zapytać. Mamy takiego wicedyrektora [...] on jest taki dosyć opiekuńczy i chętny, żeby odpowiadać na pytanie, więc w sumie nie miałam problemu (Alicja ANG5).

Trzecią grupę kodów opisujących innych nauczycieli, jako źródło emocjonalnego wsparcia, stanowią wypowiedzi badanych, w których pojawiały się odniesienia do przełożonych oraz ich roli w budowaniu poczucia własnej siły i pewności nowicjusza w szkole. $\mathrm{W}$ tych narracjach pojawiał się wątek docenienia zaangażowania i wkładu pracy.

$22 \mathrm{~W}$ opisie fragmentów wypowiedzi stosuję imię stanowiące pseudonim oraz kod badanego (złożony z: inicjału pseudonimu, $\mathrm{N}$ - nauczyciel, $\mathrm{P}$ - szkoły podstawowej, G - gimnazjum, L - liceum i numer, tj. kolejność w charakterystyce badanych; R. Wawrzyniak-Beszterda, Kapitał społeczny szkoły. 
[...] po prostu człowiek czuje się doceniony przez nich i to jest też takie motywujące i pani dyrektor mówi, zobacz to super wyszło, to, to. Musimy to zrobić jeszcze raz, że niech to się dzieje w naszej szkole to zobacz, t jest fajne (Katarzyna KNG1).

[...] pani dyrektor zawsze docenia, to co się robi, zawsze pochwali [...] Ja czuję jakby jej cały czas taką opiekę i taki nadzór. [...] Ja jestem zachwycona, naprawdę. Przez to mi się tak dobrze tam pracuje. To jest ważne... (Katarzyna KNG1).

Drugie z wyłonionych skupień związanych z przejawami wsparcia emocjonalnego jest znacznie mniej rozbudowane od poprzedniego, ma jednak swą specyficzną charakterystykę, stąd jego wyodrębnienie. Otóż w przypadku (tylko) trzech narracji źródłem emocjonalnego wsparcia dla początkujących nauczycielek byli ich uczniowie (lub członkowie ich rodziny).

[...] oni [babcie i dziadkowie uczniów uczestniczący w imprezie szkolnej R.W. B.] przyjdą, oni pochwalą, oni docenią no i to tak podbudowuje, że człowiek wręcz po prostu chce to robić, bo bo widzi w tym sens [...] (Katarzyna kng1).

[...] jak przyszedł jakiś rodzic po zebraniu [...] i powiedział, że jest fajnie [...] (Alicja ang5).

[...] i nawet do dzisiaj mam taki sprawdzian, gdzie uczeń narysował kwiatka. uczeń z 3 klasy napisał [...] dla naj... najcudowniejszej pani pod słońcem (Alicja ang5).

W jednym z przywoływanych przypadków to poczucie wsparcia i swoistego emocjonalnego współdźwięczenia z uczniami było związane z indywidualnym doświadczeniem nauczycielki bycia outsiderkq w gronie pedagogicznym. Głęboka, intensywna identyfikacja uczuciowa z uczniami i ich sytuacją, uwrażliwienie na płynące od nich oznaki sympatii oraz bliskości w przypadku Weroniki były wyborem „strony” w kontekście mobbingowych praktyk w gronie pedagogicznym.

[...) teraz to najważniejsze dla mnie, żeby mieć dobry kontakt z tymi dziećmi [...] mogę rzeczywiście z tymi dziećmi porozmawiać [...] przede wszystkim bym chciała, żeby te dzieci mnie lubiły, żeby one się dobrze czuły w tej świetlicy [...] żeby rzeczywiście czuły się takie zaopiekowane [...] (Weronika WNP3). 
W narracjach badanych nauczycieli epizody związane z doświadczanym wsparciem informacyjnym zazwyczaj obejmowały jednocześnie wsparcie o charakterze instruktażowym. Sytuacje trudne, które pojawiały się w wypowiedziach nauczycieli związane były nie tylko z deficytami o charakterze poznawczym, wynikającymi z niedoboru wiedzy na temat różnych aspektów pracy w szkole lub ich rozumienia, ale też z niedostatkiem narzędzi i rozwiązań, nieznajomości obowiązujących praktyk oraz procedur, braku skutecznych środków zaradczych. Tego rodzaju wsparcie nowicjuszy w sytuacjach trudnych stanowiło splot doświadczeń złożonych z epizodów pomocy instrumentalno-informacyjnej. $\mathrm{Z}$ uwagi na specyfikę korpusu danych wyłaniane kody wpisywały się w charakterystyki tych dwóch rodzajów wsparcia (odzwierciedlając ich swoiste sprzężenie), zdecydowałam zatem o nierozdzielaniu tej siatki kodów. W jej ramach wyodrębniały się jednak charakterystyczne skupienia, które obejmowały kody odzwierciedlające unikatowe rysy analizowanych doświadczeń biograficznych.

Siatka sformowana w odniesieniu do obecnych w narracjach przejawów wsparcia informacyjno-instruktażowego obejmowała skupienia tematyczne kodów nawiązujących do zadań związanych z budowaniem warsztatu zawodowego nauczyciela. Tutaj pierwszą grupę kodów tematycznych tworzyły te odnoszące się do zadań związanych z awansem zawodowym.

[...] nie miałam pojęcia, jak stworzyć ten plan, jak się do tego zabrać i Pani dyrektor mówi słuchaj idź do oDN-u są szkolenia odnośnie pisania planu, super są, idź, będziesz wiedziała wszystko. Poszłam na te szkolenia i po prostu dostałam wytyczne, jak ten plan napisać, o co tam chodzi w tym wszystkim. [...] Tam na tym szkoleniu to mi tam wytłumaczyli, że rzeczywiście ten plan musi cały czas działać, że można go zmienić, w każdym momencie [...] ale po tym szkoleniu jakby wszystko zupełnie inaczej na to zaczęłam patrzeć. Wtedy rzeczywiście zaczęłam widzieć sens tego planu (Katarzyna KNG1).

[...] więc zawsze to się słyszy gdzieś tam w pokoju, jak ktoś mówi, jak ja robiłem awans [...] więc staram się mieć uszy otwarte. (Alicja ANG5)

W narracjach badanych otrzymywane wsparcie stanowiło inspirację/podpowiedź zawodową, przykład warty naśladowania.

To jest nauczyciel z pasją [...] na każdy jakby problem zawsze miała rozwiązanie i to tak, tak z kapelusza. Ona od razu wiedziała, że to, to, to, przewidy- 
wała. Na przykład pamiętam, że w pierwszym roku robiła przedstawienie teatralne i nie byłam przekonana, a ona mówi, słuchaj zrób tutaj. Pokazała mi scenariusz. No, mówi, to Ci wyjdzie. Ja mówię w życiu tam. To jest takie dla, za dziecinne, a ona mówi nie spokojnie rób to. Kiedyś robiłam te przedstawienia i tak przeczytała scenariusz i mówi: wyjdzie super, nie. No i rzeczywiście dzieciaki miałam, takie, że w miarę były chętne. Zrobiliśmy to przedstawienie mimo, że to mi się wydawało dziecinne, to dzieciaki w ogóle były zachwycone i po angielsku zrobiliśmy to przedstawienie (Katarzyna KNG1).

[...] na pewno takim motorem jest, było też korzystanie z rad i jak gdyby doświadczenia osób, które pracują z ludźmi niepełnosprawnymi już bardzo długo, czy to rehabilitantów, bo myśmy się też konsultowali [...] ale naprawdę jakby uczyłam się z ich doświadczenia. [...] Nawet było tak, ze z jakiejś fundacji pani też z dziećmi tam pracował, miała córkę swoją, przychodziła do mnie i podpowiadała pewne rzeczy też [...] (Jagoda JN/P4).

Drugie skupienie konstruuje zestaw kodów tematycznych stanowiących charakterystykę osób udzielających wsparcia informacyjno-instruktażowego. Pierwszą grupę kodów łączą ujawniane we fragmentach narracji deklaracje świadczące o swoistej wspólnocie „w biedzie”: pomoc jest „świadczeniem wzajemnym", które wzmacnia poczucie bezpieczeństwa nowicjuszy wynikające z ich współudziału w trudnych sytuacjach.

[...] nowe, no to też trzymałyśmy się razem [...] bo one miały już jakieś doświadczenie. Ja byłam tylko taka, że, że dopiero zaczynałam, więc też nie bałam się, że one były nowe i wtedy się też podpytywałam, co jak zrobić, jak się zachować? (Katarzyna KNG1)

Była tak koncepcja w głowie dla młodych nauczycieli i zawsze to było wymienianie się sprawdzianami [...] wśród młodych to było dużo łatwiejsze do zrobienia [...] ale to trzeba chcieć swoją pracą się dzielić, tak z innymi za darmo. (Patrycja PNP/G2)

Kolejna tematyczna grupa kodów obecna była w narracjach, w których pojawiały się opisy sytuacji i doświadczeń związanych z proszeniem innych o pomoc i, co ważne, otrzymywaniem jej. Badani przywoływali szczególną rolę wychowawców, psychologów/pedagogów oraz dyrektorki.

Dla mnie w ogóle kontakt z psychologiem szkolnym to jest w ogóle klucz

[...] To właśnie po konsultacji z psychologiem było tak, że często jakieś 
wskazówki, a ja już dalej sobie rozwinęłam myśl i dostosowałam, bo każdy człowiek jest inny (Patrycja PNP/G2).

No wtedy pamiętam, że nie wiem, czy tak dobrze trafiłam, ale ci wychowawcy, którzy też, bo z reguły zwracam się do wychowawców i wychowawcy po prostu też rozwiązywali problem. [...] była rozmowa z tym uczniem i często też ja uczestniczyłam w tej rozmowie i potem też się uczyłam, znaczy uczyłam, no patrzyłam jak ta rozmowa prze.. jak to wygląda, jak, jak się rozmawia z takim uczniem co się mu mówi, jak się mu mówi, jak to powinno wszystko wyglądać. No i, i to jakby tego się uczyłam (Katarzyna KNG1).

[...] pierwsze co, to była zawsze pani psycholog, pani pedagog. No jeżeli były w szkole to fajnie, bo gdzieś tam mogły albo się zająć klasą, albo się zająć tym jednym dzieckiem (Ewa ENP6).

[...] spotkania z panią dyrektor i pytania, co robimy dalej? Jak pomóc? Były takie spotkania, jak najbardziej [...]zawsze czułam wsparcie, jeżeli o to chodzi, to nie mogłam powiedzieć, że nie. Także zawsze stały za mną i zawsze próbowały jakoś pomóc i zrobić w tej sytuacji (Ewa ENP6).

Trzecie skupienie kodów buduje charakterystykę szkolnych barier wsparcia informacyjno-instruktażowego, których przykłady/przejawy/opisy obecne były w narracjach badanych. I tak pierwsza grupa kodów w tym skupieniu identyfikowana była w narracjach, w których pojawiały się próby zrozumienia/wyjaśnienia braku pomocy. Badani łączyli takie sytuacje z cechami osobowymi kolegów/koleżanek i ich niechęcią wobec bezinteresownego dzielenia się własnym dorobkiem zawodowym.

Nie wiem, może inni są zamknięci bardziej. Nie chcą, nie chcą pomagać, bo nie wiem myślą, że to jest ich warsztat, nie wiem, oni sobie sami to wypracowali, dlaczego komuś mają ten warsztat np. oddawać, albo no przyszła młoda, jest po studiach, to wie, co powinna wiedzieć, to musi sobie jakoś poradzić. Nie wiem, myślę, że dużo może być takich powodów, albo, nie wiem, dlaczego ona ma być lepsza ode mnie, czy, czy, czy dlaczego, dlaczego mam jej pomagać skoro no niech ona teraz się wykaże. To dużo było takich nauczycieli , którzy właśnie mieli to takie, takie podejście (Ewa ENP6).

[...] wymienianie się sprawdzianami [...] musiało mieć, powiedzmy, musiała się pojawić atmosfera pewnej przysługi, że to nie było naturalne, że się daje sprawdzian komuś, tylko to musiało mieć taki wydźwięk, że dziękuję ci za ten sprawdzian (Patrycja PNP/G2). 
Trzeba było mi pokazać, że mam być jakby w szeregu, nie? I to było ciężkie pod tym względem jako młodego nauczyciela [...] (Jagoda JN/P4).

Są nauczyciele, którzy pomogąa, ale często jest tak, że nie wiem czy to wynika ze złej woli czy z czego. Na przykład prosiłam niedawno koleżankę [...] ale ile można prosić. Jak koleżanka nie wysyła po którymś razie, po którejś prośbie to znaczy, że nie chce... (Alicja ANG5).

[...] mój opiekun akurat totalnie, totalnie nie mogę liczyć, bo akurat tutaj jest taka sprawa, że jestem właściwie opiekunem tego pana, bo ten pan mało się angażuje i miał długą przerwę w pracy w szkole, więc akurat... Znaczy nie przeszkadza mi to, jakoś sobie radzę (Alicja ANG5).

W narracjach dotyczących startu zawodowego pojawiały się wypowiedzi świadczące o obawach nowicjuszy przed przyznaniem się do niewiedzy, która przez otoczenie postrzegana była jako dowód ich zawodowej niekompetencji.

Może czasami głupio było pytać o coś, znaczy, wiedziałam, że zadawać za wiele pytań też nie jest dobrze, bo ktoś pomyśli, że jestem nieprofesjonalna i że może nie nadaję się na nauczyciela (Alicja ANG5).

[...] jestem otwarta, ale jest to zawsze poczytywane jako moja nieporadność i to mnie jakby gdzieś tam hamuje w tym, żeby cokolwiek już przekazywać i staram się zawsze rozwiązać to, jakiś problem na poziomie tutaj najbliższego środowiska [...] Zabrakło mi takiej podstawowej opieki. [...] miałam wrażenie, co mnie trochę tak w gronie nauczycielskim trochę jakoś tak degradowało, że jednak jestem zawsze ta młoda, ta po studiach, na nią trzeba uważać, bo ona zawsze popełni błąd [...] (Weronika WNP3).

Wsparcie, które w specyficzny sposób miało charakter pomocy rzeczowej, pojawiło się w narracjach tylko dwóch nauczycielek.

[...] pani dyrektor tak się spodobałam, że jakby wyszukała jeszcze godziny, pół etatu. Powiedziała, że dam Ci dziecko szanse. Jesteś młoda. Dam ci pół etatu, żebyś zrobiła ten staż, a potem pójdziesz sobie w świat, bo tutaj, no mówi, że nie wiadomo, no różnie z tymi godzinami jest, że to nie jest zależne od niej, ale tak jakoś mówi, że no. No chciała dać mi szansę. Po prostu takie miała, odruch serca można to nazwać bo dlaczego... (Katarzyna KNG1).

[...] bo ja mówię, ile muszę kupić tych książek. A one mówią: no co ty, to się nie kupuje, że to tam się dzwoni do wydawnictwa i że będzie się z tego 
i tego korzystało [...] bo też byłam przerażona zakupem tylu zestawów, tego wszystkiego [...] (Katarzyna KNG1).

Narracje nauczycieli odsłaniające przejawy wsparcia strukturalnego były najsłabiej obecne w wypowiedziach badanych. Tylko jedna nauczycielka skorzystała na początku swej pracy ze szkoleń organizowanych przez ośrodek doskonalenia nauczycieli, a dowiedziała się o tej możliwości dzięki rekomendacji dyrektorki szkoły. Instytucjonalna bezradność pojawiła się w wypowiedzi nauczycielki, opisującej swoje doświadczenie niepowodzenia wychowawczego, które związane była ze skrajnie trudnymi zachowaniami jednego z uczniów, jego agresją w relacjach rówieśniczych oraz brakiem współpracy z rodziną. Sprawa znalazła epilog w sądzie, ale rozstrzygnięcia, które zapadły tylko wzmocniły poczucie osamotnienia i bezradności nauczycielki oraz utratę wiary w możliwość uzyskania skutecznej pomocy.

[...] w sądzie, sędzina bodajże orzekła, że to są sytuacje bezpodstawne i nie dochodzi, aż do jakiś, nie wiem, nie wiadomo jakich sytuacji, żeby coś w tej sprawie zrobić i niczym się nie zakończyło, żadną, żadną, żadną karą, żadnym, no niczym, niczym. Tam tylko tyle, że oni mieli założoną niebieską kartę, ta rodzina, no, ale to nic nie wniosło [...] założenie sprawy na policji, no ale tutaj widzimy, że w takiej sytuacji już naprawdę drastycznej nie przyniosło to żadnych rezultatów, także mamy naprawdę związane ręce w takich sytuacjach trudnych (Ewa ENP6).

Portret dostępnego w szkole wsparcia społecznego dla początkujących nauczycieli w trakcie ich startu zawodowego ma nieharmonijną kompozycję: wyodrębnione rodzaje wsparcia są obecne w przestrzeni szkoły w zróżnicowanym nasileniu. Charakterystyka doświadczanego przez nowicjuszy wsparcia wyłoniona $\mathrm{z}$ narracji badanych lokuje je w przestrzeni relacji interpersonalnych, w tym sensie, że „odsłonięcie” swych zawodowych braków/deficytów wymaga od nowicjuszy poczucia bezpieczeństwa w relacji. W konsekwencji, w szkole mamy do czynienia ze swoistym sprywatyzowaniem wsparcia: pojawia się ono w odniesieniach zbudowanych na poczuciu bliskości z partnerem interakcyjnym, zaufaniu do niego, uznaniu jego kompetencji. To zjawisko wydaje się naturalne, ale nabiera niepokojącego znaczenia w kontekście odsłanianych w doświadczeniach badanych nauczycieli deficytów rozwiązań organizacyjnych i strukturalnych, które stano- 
wiłyby źródło niezbędnego „na starcie” wsparcia w radzeniu sobie z wymaganiami zawodowymi. W szkole brakuje utrwalonych sposobów wspierania nowicjuszy $\mathrm{w}$ procesie stawania się nauczycielem, dobrych praktyk umożliwiających im czerpanie z zasobów kultury organizacyjnej środowiska pracy. W zasadzie często swej roli nie spełnia nawet opiekun stażu, którego zadaniem jest przecież dzielenie się wiedzą i doświadczeniami, inspirowanie do podejmowania wyzwań zawodowych, wspieranie nauczyciela w procesie jego wdrażania się do pracy w zawodzie. Osamotnienie nauczycieli w radzeniu sobie z wymaganiami pracy w szkole petryfikuje obawa przed upublicznieniem porażek w otoczeniu, w którym nie ma atmosfery zrozumienia. Wobec niedoboru systemowego wsparcia w postaci sieci i struktur nowicjusz może stać się zakładnikiem swego braku doświadczenia.

Streszczenie: Problematyka artykuły dotyczy doświadczeń biograficznych początkujących nauczycieli związanych z ich startem zawodowym. Analiza ich narracji (reanaliza wywiadów swobodnych ukierunkowanych) pozwoliła zarysować mapę wsparcia społecznego obecnego w szkole.

Słowa kluczowe: początkujący nauczyciele, start zawodowy, rozwój zawodowy nauczyciela, wsparcie społeczne, dane jakościowe, reanaliza.

\section{Bibliografia}

Denzin N. K., Reinterpretacja metody biograficznej $w$ socjologii: znaczenie a metoda $w$ analizie biograficznej, tłum. N. Nowakowska, w: Metoda biograficzna w socjologii, red. J. Włodarek, M. Ziółkowski, Warszawa-Poznań 1990, s. 55-70.

Domecka M., Praca jako doświadczenie biograficzne, w: Konstruowanie jaźni i społeczeństwa. Europejskie warianty interakcjonizmu symbolicznego, red. E. Hałas, T. Konecki, Warszawa 2005, s. 229-250.

Dróżka W., Młode pokolenie nauczycieli. Studium autobiografii młodych nauczycieli polskich lat dziewięćdziesiątych, Kielce 1997.

Gibbs G., Analizowanie danych jakościowych, tłum. M. Brzozowska-Brywczyńska, Warszawa 2011.

Grochowalska M., Dylematy nowicjusza. Konteksty stawania się nauczycielem edukacji przedszkolnej, „Edukacja Elementarna”, 9 (2014) nr 1 (31), s. 27-40.

Karkowska M., Bielińska M., Po co nam „stare wywiady”? O ponownym wykorzystaniu danych $z$ badań jakościowych (rewizytach, reanalizach i nie tylko), „Przegląd Socjologii Jakościowej", 15 (2019) nr 3, s. 12-39. 
Keller-Schneider M., Entwicklungsaufgaben im Berufseinstieg von Lehrpersonen. Beanspruchung durch berufliche Herausforderungen im Zusammenhang mit Kontextund Persönlichkeitsmerkmalen, Münster 2010.

Kędzierska H., Nowicjusze: proces zakotwiczania w zawodzie nauczyciela, „Forum Oświatowe", 27 (2015) nr 2 (15), s. 59-73.

Klus-Stańska D., Ciągłość i zmiana czy bierność i niekontrolowane odruchy-w którym kierunku zmierza szkoła? w: Ciągłość i zmiana w edukacji szkolnej-społeczne i wychowawcze obszary napięć, red. J. Surzykiewicz, M. Kulesza, Łódź 2010, s. 35-49.

Kvale S., InterViews. Wprowadzenie do jakościowego wywiadu badawczego, tłum. S. Zabielski, Białystok 2004.

Kwiatkowska H., Pedeutologia, Warszawa 2008.

Sęk H., Wsparcie społeczne jako kategoria zasobów, w: Zasoby osobiste i społeczne sprzyjające zdrowiu jednostki, red. Z. Juszczyński, N. Ogińska-Bulik, Łódź 2003, s. 17-32.

Sęk H., Cieślak R., Wsparcie społeczne - sposoby definiowania, rodzaje i źródła wsparcia, wybrane koncepcje teoretyczne, w: Wsparcie społeczne, stres i zdrowie, red. H. Sęk, R. Cieślak, Warszawa 2004, s. 11-28.

Stake R. E., Jakościowe studium przypadku, w: Metody badań jakościowych, t. 1, red. N. K. Denzin, Y. S. Denzin, tłum. M. Sałkowska, Warszawa 2009, s. 623-654.

Szempruch J., Pedeutologia. Studium teoretyczno-pragmatyczne, Kraków 2013.

Terhart E., Lehrerberuf und Lehrerbildung. Forschungsbefunde, Problemanalysen, Reformkonzepte, Weinheim-Beltz 2001.

Walczak D., Początkujący nauczyciele. Raport z badania jakościowego, Warszawa 2012. Wawrzyniak-Beszterda R., Kapitał społeczny szkoły. Z doświadczeń biograficznych nauczycieli. Studium przypadków, Poznań 2019. 